\title{
The effects of the presence of the corneal epithelium and supplemental hydrocortisone on $\beta$-glucuronidase levels with corneal preservation
}

This article was published in the following Dove Press journal:

Clinical Ophthalmology

29 March 201I

Number of times this article has been viewed

\section{Thomas Mauger}

Eric Quartetti

Havener Eye Institute,

Department of Ophthalmology,

The Ohio State University, OH, USA
Purpose: To analyze the levels of $\beta$-glucuronidase during prolonged (14 day) corneal preservation with epithelialized (EPI) and deepithelialized (DEP) corneas and the effect of supplemental hydrocortisone (HCT) on these levels.

Methods: Thirty-six freshly excised bovine corneas were preserved in Optisol solution $\left(4^{\circ} \mathrm{C}\right)$ for 14 days with the following conditions EPI/no supplemental HCT, DEP no supplemental $\mathrm{HCT}, \mathrm{EPI} / 10^{-8} \mathrm{M}$ HCT, and EPI $10^{-4} \mathrm{M}$ HCT. $\beta$-glucuronidase activity levels were measured at the end of this period.

Results: $\beta$-glucuronidase levels $(\mathrm{nmol} / \mathrm{mL} / \mathrm{h}$ ) for each group were found to be: EPI - No HCT: 4.302, SEM 0.586; DEP - No HCT: 2.178, SEM 0.271; EPI - 10-8 M HCT: 4.472, SEM 0.435 EPI $-10^{-4}$ M HCT: 2.072, SEM 0.437. The EPI - No HCT and EPI $-10^{-8}$ M HCT were not significantly different as were the DEP - No HCT and EPI $-10^{-4} \mathrm{M}$ HCT groups. The EPI - No HCT group and the EPI $-10^{-8} \mathrm{M}$ HCT group were independently significantly different from the DEP - No HCT and the EPI $-10^{-4} \mathrm{M}$ HCT groups.

Conclusions: The corneal epithelium contributes significantly to the formation of the lysosomal enzyme, $\beta$-glucuronidase, during preservation. The addition of $10^{-4} \mathrm{M}$ HCT decreases the production of $\beta$-glucuronidase during corneal preservation in this model.

Keywords: $\beta$-glucuronidase, preservation

\section{Introduction}

Proteolytic lysosomal enzyme activity may be responsible for detrimental effects on the corneal endothelium. ${ }^{1,2}$ Glycolytic lysosomal enzymes have been studied less extensively and their role in endothelial cell loss during corneal preservation is still incompletely understood. ${ }^{3}$ The use of adjuvant corticosteroid in the preservation medium has demonstrated reduced levels of glycolytic lysosomal enzymes. ${ }^{4,5}$ However, the lysosomal activity found during preservation for routine corneal transplantation did not correlate with graft success. ${ }^{6}$ The mean corneal storage time in this study was 73 hours. ${ }^{6}$ The question of whether lysosomal activity at longer preservation times (14 days) may be more substantial and could be reduced through the use of corticosteroids has not been completely addressed. The second question to be addressed is the magnitude of the source of the glycolytic lysosomal enzymatic activity. If, as expected, it is from the cellular elements of the cornea, then removal of the corneal epithelium should have a substantial effect on the measured glycolytic enzymatic activity.
Correspondence: Thomas Mauger Havener Eye Institute, Department of Ophthalmology, The Ohio State University, OSU Eye and Ear Institute, 915 Olentangy River Road, Columbus, $\mathrm{OH} 43212$, USA

Tel +I 6142935635

Fax + 6142933167

Email thomas.mauger@osumc.edu 


\section{Materials and methods}

\section{Tissue}

All corneas were obtained from freshly slaughtered bovine within six hours of death. Nine of the eyes were selected for mechanical deepithelialization prior to removal of the corneoscleral rim in order to protect the corneal endothelium. The remaining 27 eyes had intact corneal epithelium as determined by slit lamp examination. The corneoscleral excisions were performed using sterile technique leaving a $3-\mathrm{mm}$ scleral rim. The corneas were then placed in the prepared Optisol and HCT modified Optisol solution. They were stored for 14 days at $4^{\circ} \mathrm{C}$. At the conclusion of the preservation, $5 \mathrm{~mL}$ of the solution was frozen in dry ice and transported frozen for $\beta$-glucuronidase activity.

\section{Solution preparation}

The hydrocortisone solution was prepared in the following manner by the Admixture Pharmacy Department at The Ohio State University Hospitals. Water-soluble hydrocortisone powder (Sigma H0396) was dissolved aseptically in the Optisol to achieve a final concentration of $10^{-8} \mathrm{M}$ in nine containers and $10^{-4} \mathrm{M}$ in nine containers.

\section{$\beta$-glucuronidase activity measurements}

At the conclusion of the preservation period, $5 \mathrm{~mL}$ of the Optisol solution was removed from the chamber and immediately frozen with dry ice and transported to the Mayo Medical Laboratories for measurement of the $\beta$-glucuronidase activity using the CSF protocol. The substrate, phenolphthalein mono- $\beta$-glucuronic acid, is hydrolyzed by the enzyme at $\mathrm{pH} 4.5$ for 18 hours. The phenolphthalein liberated is measured spectrophotometrically at $550 \mathrm{~nm}^{7}$

\section{Results}

The $\beta$-glucuronidase activity for each group is shown in Table 1. The activity for the EPI- No HCT (control) group (Mean: 4.302; SEM: 0.586) and the EPI $-10^{-8} \mathrm{M}$ HCT Group (Mean: 4.472; SEM 435) were found to be not significantly different (Tukey Test, confidence level of 95\%). The DEP-No HCT group (Mean: 2.178; SEM: 0.271) and the EPI $-10^{-4} \mathrm{M}$ HCT Group (Mean: 2.072; SEM: 0.437) was not found to be significantly different (Tukey Test, confidence level of 95\%). The EPI-No HCT Group and the EPI $-10^{-4} \mathrm{M}$ HCT groups were each found to be significantly different than the DPI - No HCT and the EPI $10^{-8}$ M HCT groups (Tukey Test, confidence level of $95 \%$ ).
Table I $\beta$-glucuronidase activity $(\mathrm{nmol} / \mathrm{mL} / \mathrm{h})$

\begin{tabular}{lllll}
\hline Group & N & Mean* & SE mean & SD \\
\hline EPI - No HCT & 9 & 4.302 & 0.586 & 1.758 \\
DEP - No HCT & 9 & 2.178 & 0.271 & 0.813 \\
EPI - I0-8 M HCT & 9 & 4.472 & 0.435 & 1.304 \\
EPI - 10-4 M HCT & 9 & 2.072 & 0.437 & 1.312 \\
\hline
\end{tabular}

Note: One way ANOVA: $P=0.000$

\section{Conclusions}

Lysosomal activity during corneal preservation is an indicator of tissue autolysis. Endothelial cell damage may occur from proteolytic lysosomal enzymes. ${ }^{1,2}$ The addition of corticosteroid to the preservation solution has been shown to reduce lysosomal enzyme activity and to have a protective effect on the corneal endothelium. ${ }^{4,5}$ Lysosomal enzyme levels have not been found to correlate as a predictor of graft outcome in an analysis of lysosomal enzyme levels from a solution of preserved corneas used for penetrating keratoplasty with relatively short periods of preservation (73 hours). ${ }^{6}$

This study indicates that $\beta$-glucuronidase activity for prolonged corneal preservation $\left(14\right.$ days, $\left.4^{\circ} \mathrm{C}\right)$ may be reduced in two ways. First, by removing the metabolically active corneal epithelium prior to preservation. The second method is by adding water-soluble hydrocortisone to achieve a concentration of $10^{-4} \mathrm{M}$. While the lysosomal enzyme activity was not found to correlate with graft success it may be that reducing lysosomal activity by these methods will allow longer preservation times and viable endothelium. ${ }^{6}$ A study compared a hydrocortisone supplemented solution (H-Sol) to Optisol with 12 day preservation and found similar endothelial cell loss for each group. Lysosomal enzyme activity was not measured in this study and there are other differences other than supplemental steroid in the two solutions used in this study. ${ }^{7}$

In summary, we found substantial reduction in $\beta$-glucuronidase activity with the removal of the corneal epithelium and with the additional of $10^{-4} \mathrm{M}$ hydrocortisone. Whether this will correlate with improved corneal endothelium and the ability to preserve corneas longer is as yet unknown.

\section{Disclosure}

The authors report no conflicts of interest in this work.

\section{References}

1. Arya DV, Mannaugh J, Irvine AR. Effects of lysosomes on cultured rabbit corneal endothelial cells. Invest Ophthalmol. 1972;11:662-667.

2. Arya DV, Mannaugh J, Irvine AR, Levine RE, Yuhasz Z. Effect of lysosomes on corneal endothelium: an in vivo study. Invest Ophthalmol. 1972;11:655-661. 
3. Basu PK, Hasany S. Autolysis of the corneas of human donor eyes. Can J Ophthalmol. 1974;9:229-235.

4. Basu PJ, Hasany SM, Doane FW, Schultes K. Can steroid reduce endothelial damage in stored corneas? Effect on cell viability and ultrastructure. Can J Ophthalmol. 1978;13(1):31-38.

5. Fook TJ, Ranadive NS, Basu PK. The prevention of autolysis of stored cornea using steroid as a lysomal membrane stabilizer. Can J Ophthalmol. 1975;10(4):482-486.
6. Wiffen SJ, Hodge DO, Nelson LR, Bruner WE, Bourne WM. Lysosomal enzymes in corneal storage media and corneal graft outcome. Cornea. 1997;16(2):169-176.

7. Plaice C. A note on the determination of serum beta-glucuronidase activity. J Clin Pathol. 1961;14:661-665.

8. Vila J, Hasany SM, Parker JA, Rootman DS. In-vitro comparative study of a locally prepared corneal storage medium and Optisol. Can J Ophthalmol. 1996;31(5):217-220.

\section{Publish your work in this journal}

Clinical Ophthalmology is an international, peer-reviewed journal covering all subspecialties within ophthalmology. Key topics include: Optometry; Visual science; Pharmacology and drug therapy in eye diseases; Basic Sciences; Primary and Secondary eye care; Patien Safety and Quality of Care Improvements. This journal is indexed on

Submit your manuscript here: http://www.dovepress.com/clinical-ophthalmology-journal

\section{Dovepress}

PubMed Central and CAS, and is the official journal of The Society of Clinical Ophthalmology (SCO). The manuscript management system is completely online and includes a very quick and fair peer-review system, which is all easy to use. Visit http://www.dovepress.com/ testimonials.php to read real quotes from published authors. 